\title{
PERANCANGAN SISTEM PAKAR MENDIAGNOSA PENYAKIT GINJAL DENGAN PENGOBATAN HERBAL
}

\author{
Relita Buaton, ST., M.Kom. ${ }^{1}$, Yani Maulita, S.Kom.,M.Kom. ${ }^{2}$ \\ STMIK KAPUTAMA, Jln. Veteran No. 4A-9A \\ Binjai, Indoesia
}

\begin{abstract}
Abstrak
Perkembangan computer desawa ini telah mengalami banyak perubahan yang sangat pesat, seiring dengan kebutuhan manusia semakin banyak dan kompleks. Salah satu implementasi yang diterapkan system pakar dalam bidang kesehatan ginjal. Perancangan system pakar untuk mendiagnosa penyakit ginjal dengan metode forward chaining bertujuan untuk melakukan konsultasi tanpa harus bertemu dengan dokter yang memakan biaya dan waktu. Sistem pakar ini menggunakan metode representasi kaidah produksi untuk mempresentasikan pengetahuan tentang penyakit ginjal beserta gejala dan pencegahannya. Hasil uji konsultasi dengan system ini menunjukkan bahwa system mampu menetukan jenis penyakit yang diderita pasien dengan disertai terapi, dan pencegahannya, berdasarkan data-data gejala yang dipilih pengguna.
\end{abstract}

Kata Kunci : Sistem Pakar, Ginjal, Forward Chaining, Pengobatan Herbal, Mendiagnosa, Penyakit

\section{PENDAHULUAN}

\subsection{Latar Belakang Masalah}

Perkembangan teknologi yang pesat saat ini membuat arus kebutuhan informasi turut berkemban cepat. Seiring berkembangnya dunia teknologi khususnya dunia komputerisasi,maka dibutuhkan suatu sistem yang dapat membantu manusia menangganin masalah-masalah dikehidupan sehari-hari. Saat ini manusia membutuhkan aplikasi dalam bidang kesehatan khususnya aplikasi yang dapat mendiagnosa penyakit. Dalam hal ini penulis mengambil penyakit ginjal sebagai contoh. Sistem pakar yang dirancang diharapkan dapat membantu mengenalin dan memahami penyakit ginjalyang diderita oleh pasien.

Artificial intelligence (AI) dapat dipertimbangsebagai alat yang dapat menyamai pikiran manusia untuk menolong dalam memecahkan masalah.

Sistem Pakar (expert system) adalah sistem yang mendapatkan dan menyimpan pengetahuan mausia kedalam komputer untuk menyelesaikan permasalahan yang biasanya membutuhkan kepakaran seorang ahli

\subsection{Rumusan Masalah}

Meninjau dari pokok permasalahan yang telah diuraikan pada latar belakang masalah di atas dapat diambil rumusan sebagai berikut:

1. Bagaimana cara untuk mempermudah user mengetahui penyakit kerusakan gigi apa yang diderita user dari gejala-gejala yang ada?

2. Bagaimana menciptakan sebuah perangkat lunak yang dapat digunakan untuk membantu pembelajaran dalam bidang kedokteran ginjal dalam arti lain sebagai tutorial?

\subsection{Tujuan Penelitian}

ini adalah:

Adapun tujuan penyusunan Penelitian

1. Untuk merancang suatu perangkat lunak yang mampu mengetahui masalah gangguan ginjal yang sedang dialami pasien.

2. Untuk memberikan informasi kepada masyarakat tentang pentingnya merawat dan menjaga kesehatan ginjal.

3. Memberikan kesempatan untuk belajar memahami dan memecahkan berbagai permasalahan yang terjadi sesuai dengan disiplin ilmu masing-masing.

\subsection{Manfaat Penelitian}

Adapun manfaat dari penyusunan Penelitian ini, yaitu:

1. Untuk membantu memecahkan masalah yang sedang dihadapi penderita gangguan ginjal, dapat sesegera mungkin mendapatkan penanganan lebih dini pada gangguan penyakit ginjal.

2. Untuk memudahkan bagi tim medis,terutama para dokter dalam pengidentifikasian penyakit yang diderita oleh pasien. 


\section{LANDASAN TEORI}

\subsection{Sistem Pakar}

Sistem pakar adalah sistem perangkat lunak komputer yang menggunakan ilmu, fakta, dan teknik berpikir dalam pengambilan keputusan untuk menyelesaikan masalah-masalah yang biasanya hanya dapat diselesaikan oleh tenaga ahli dalam bidang yang bersangkutan. Dalam penyusunannya, sistem pakar mengkombinasikan kaidah-kaidah penarikan kesimpulan (inference rules) dengan basis pengetahuan tertentu yang diberikan oleh satu atau lebih pakar dalam bidang tertentu. Kombinasi dari kedua hal tersebut disimpan dalam komputer, yang selanjutnya digunakan dalam proses pengambilan keputusan untuk penyelesaian masalah tertentu.

Keahlian adalah suatu kelebihan penguasaan pengetahuan di bidang pengetahuan tertentu yang diperoleh dari pelatihan, membaca atau pengalaman.

\subsection{Struktur Sistem Pakar}

\section{Basis Pengetahuan (Knowledge base)}

Basis pengetahuan merupakan inti dari suatu sistem pakar, yaitu berupa representasi pengetahuan dari pakar. Basis pengetahuan tersusun atas fakta dan kaidah. Fakta adalah informasi tentang objek, peristiwa, atau situasi. Kaidah adalah cara untuk membangkitkan suatu fakta baru dari fakta yang sudah diketahui. Menurut Gondran (1986) dalam Utami (2002), basis pengetahuan merupakan representasi dari seorang pakar, yang kemudian dapat dimasukkan kedalam bahasa pemrograman khusus untuk kecerdasan buatan (misalnya PROLOG atau LISP) atau shell sistem pakar (misalnya EXSYS, PC-PLUS dan CRYSTAL)

\section{Mesin Inferensi (Inference Engine)}

Mesin inferensi berperan sebagai otak dari sistem pakar. Mesin inferensi berfungsi untuk memandu proses penalaran terhadap suatu kondisi, berdasarkan pada basis pengetahuan yang tersedia. Di dalam mesin inferensi terjadi proses untuk memanipulasi dan mengarahkan kaidah, model, dan fakta yang disimpan dalam basis pengetahuan dalam rangka mencapai solusi atau kesimpulan. Dalam prosesnya, mesin inferensi menggunakan strategi penalaran dan strategi pengendalian.

Strategi pengendalian berfungsi sebagai panduan arah dalam melakukan prose penalaran. Terdapat tiga tehnik pengendalian yang sering digunakan, yaitu forward chaining, backward chaining, dan gabungan dari kedua teknik pengendalian tersebut.

a. Forward Chaining

Forward chaining atau runut maju memiliki arti mempergunakan himpunan kaidah kondisi aksi. Dalam metode ini kaidah interpreter mencocokkan fakta atau statement dalam pangkalan data dengan situasi yang dinyatakan dalam anticendent atau kaidah if. Bila fakta dalam pangkalan data telah sesuai dengan kaidah if maka kaidah distimulasi. Proses ini diulang hingga didapatkan hasil.

\section{Basis Data (Database)}

Basis data terdiri atas semua fakta yang diperlukan, dimana fakta-fakta tersebut digunakan untuk memenuhi kondisi dari kaidah-kaidah dalam sistem. Basis data menyimpan semua fakta, baik fakta awal pada saat sistem mulai beroperasi, maupun fakta-fakta yang diperoleh pada saat proses penarikan kesimpulan sedang dilaksanakan. Basis data digunakan untuk menyimpan data hasil observasi dan data lain yang dibutuhkan selama pemrosesan.

\subsection{Tanaman Herbal}

Istilah Herbal biasanya dikaitkan dengan tumbuh-tumbuhan yang tidak berkayu atau tanaman yang bersifat perdu. Dalam dunia pengobatan, istilah herbal memiliki makna yang lebih luas, yaitu segala jenis tumbuhan dan seluruh bagianbagiannya yang mengandung satu atau lebih bahan aktif yang dapat dipakai sebagai obat. Misalnya mengkudu hutan (Morinda citrifolia) mengandung Morindin, bahan aktif anti kanker; Pegagan (Centela Asiatica) mengandung Asiaticoside yang berguna untuk masalah kulit dan meningkatkan IQ.

\subsection{Ginjal}

Ginjal adalah organ ekskresi dalam vertebrata yang berbentuk mirip kacang. Sebagai bagian dari sistem urin, ginjal berfungsi menyaring kotoran dari darah dan membuangnya bersama dengan air dalam bentuk urin.

\subsubsection{Anatomi Ginjal}

Bagian paling luar dari ginjal disebut korteks, bagian lebih dalam lagi disebut medulla. Pada bagian medulla ginjal manusia dapat pula dilihat adanya piramida 
yang merupakan bukaan saluran pengumpul. Struktur paling mendasar pada ginjal adalah nephrons. Masing-masing ginjal memiliki satu juta struktur mikroskopis ini yang berfungsi menyaring darah dan membuang limbah buangan. Pembuluh darah darah arteri menyalurkan darah ke ginjal setiap hari, 180 liter atau 50 galon. Ketika darah memasuki ginjal, maka ia akan disaring dan dikembalikan ke jantung melalui pembuluh darah vena.

\section{METODOLOGI PENELITIAN}

\subsection{Analisis Sistem}

Berdasarkan identifikasi masalah dapat disimpulkan bahwa prinsip kerja pada sistem pakar untuk mendeteksi penyakit ginjal adalah sebagai berikut :

1. Membuat basis pengetahuan yang mampu menampung data gejala-gejala penyebab ginjal.

2. Membangun basis pengetahuan untuk menganalisa suatu masalah tertentu dan selanjutnya akan mencari penyakit apa yang diderita oleh user.

3. Merancang antarmuka pemakai yang dapat menjangkau semua kebutuhan user tanpa mempersulit atau membingungkan user dalam penggunaan system

\subsection{Kebutuhan Informasi}

Kebutuhan Informasi pada sistem yang baru ini adalah mengenai gejala-gejala yang timbul, nama jenis- jenis kerusakan ginjal yang ditimbulkan oleh gejala-gejala tersebut dan juga alternatif pengobatan yang akan disarankan oleh dokter gnjal yang nantinya akan digantikan oleh sistem yang dirancang.

\subsection{Perancangan Sistem}

\subsubsection{Perancangan Proses}

Dalam merancang sistem pakar penyakit ginjal ini penulis menggunakan metode forward chaining dalam menyelesaikan masalah, sistem diagnosa yang dirancang menyesuaikan gejala user dengan kesimpulan yang dikumpulkan ke dalam database. Adapun langkah-langkah yang penulis lakukan untuk mendiagnosa penyakit ginjal adalah sebagai berikut:

1. Mengumpulkan teori-teori tentang penyakit ginjal.

Dalam tahapan ini, penulis mengumpulkan teori -teori yang berhubungan dengan penyakit ginjal, perancangan aplikasi menggunakan PHP dan
MySQL. Teori-teori ini penulis kumpulkan dari beberapa sumber seperti buku -buku di perpustakaan, artikel-artikel di internet.

2. Merancang program

Setelah teori-teori penunjang penulis rasakan cukup, langkah selanjutnya penulis melakukan perancangan terhadap program. Program yang dirancang untuk melakukan pencocokan antara gejala user dengan penyakit yang telah dikumpulkan di dalam database.

Langkah pertama dalam perancangan program ini adalah merancang proses kerja sistem. Proses kerja sistem penulis rancang menggunakan sebuah bagan alir (flowchart) yang menjelaskan secara rinci proses-proses yang akan dilakukan program dalam melakukan diagnosa.

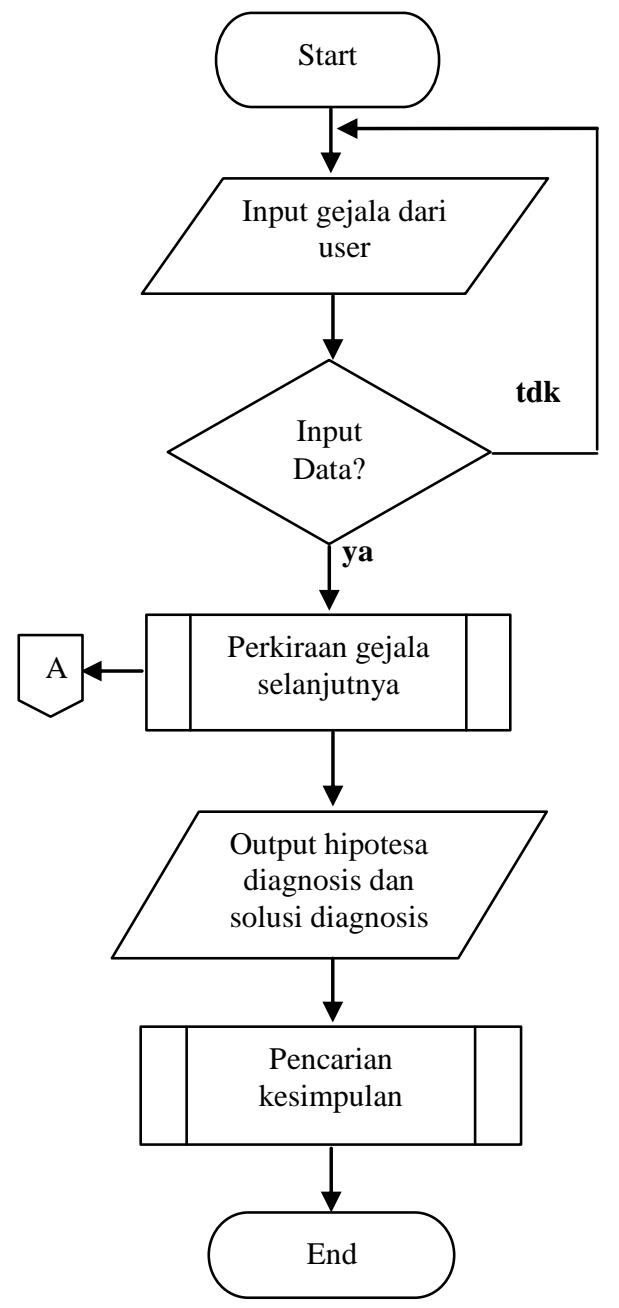

Gambar III.1 Flowchart diagnosa penyakit 
Selanjutnya untuk memahami bagaimana system yang nantinya akan dibangun dapat dilihat proses system secara garis besar melalui Data Flow Diagram (DFD) seperti diagram berikut ini :

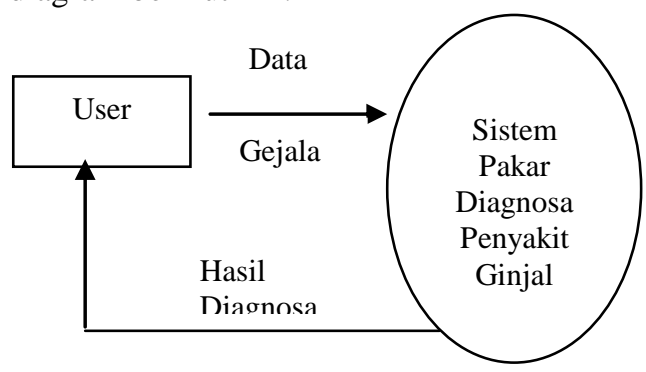

\section{Gambar III.3 DFD Level 0 Sistem Pakar Penyakit Ginjal}

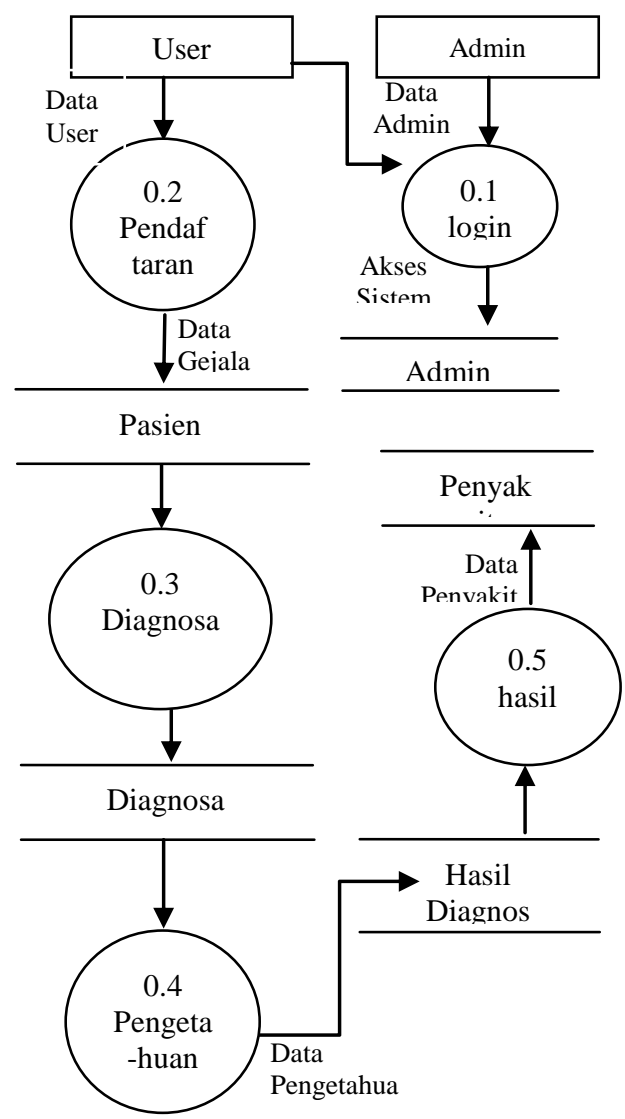

Gambar III.4 DFD Level 1 Sistem Pakar Penyakit Ginjal

\subsubsection{Perancangan Basis Data}

Basis pengetahuan yang terdapat dalam perangkat lunak terdiri dari basis aturan dan basis gejala atau kerusakan. Basis pengetahuan tersebut disimpan ke dalam baris data. Proses ini berguna agar penelusuran data, penyimpanan data, dan perubahan data dapat dilakukan dengan mudah. Basis Data merupakan suatu media penyimpanan yang digunakan untuk menyimpan data-data penunjang sebagai inputan sistem dan kemudian diolah menjadi output sistem. Basis Data dibuat dengan menggunakan MySQL.

\subsubsection{Perancangan Kamus Data}

Berikut ini rancangan kamus data dari system pakar penyakit ginjail

1. Table admin $=\{$ @id + user name + password \}.

2. Tabel diagnosis $=\{@$ @id_diagnosis + diagnosis + ifyes + ifno $\}$

3. Tabel Hasil_Diagnosis $=\{$ @id_hasil_diagnosis + tanggal_periksa + id_rekam_medis + id_diagnosis + id_penyakit

4. Table Pasien $=\{@$ @id_rekam_medis + nama_pasien + umur + alamat + jenis kelamin + no.telfon $\}$

5. tabel penyakit $=\{$ @id_penyakit + nama_penyakit + terapi $\}$

Adapun ERD yang tercipta dari normalisasi database diatas adalah sebagai berikut :

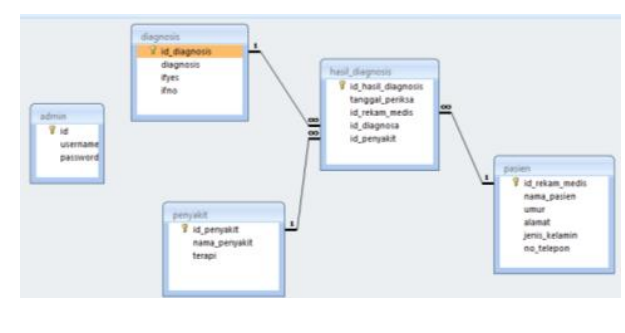

Gambar III.5 Relasi Tabel

\subsubsection{Basis Pengetahuan}

Basis pengetahuan merupakan representasi dari hasil proses akuisisi pengetahuan dimana dalam akuisisi pengetahuan ini dilakukan pengumpulan data-data pengetahuan yang menjadi satu masalah dari pakar dan dijadikan dokumentasi untuk diolah dan diorganisasikan menjadi pengetahuan.

Pada Bagian ini diberikan contoh proses akuisisi dan representasi pengetahuan suatu perangkat dalam hal ini adalah gejalagejala dan penyakit, seperti pada tabel III.3.

Tabel III.6 Tabel Keputusan GejalaGejala dan Penyakit

\begin{tabular}{|l|l|l|l|l|}
\hline No & Penyakit \& Gejala & A & B & C \\
\hline
\end{tabular}




\begin{tabular}{|c|c|}
\hline 1 & $\begin{array}{l}\text { Berkurangnya } \\
\text { produksi air kemih }\end{array}$ \\
\hline 2 & $\begin{array}{l}\text { Pembengkakan } \\
\text { tungkai, kaki atau } \\
\text { pergelangan kaki }\end{array}$ \\
\hline 3 & $\begin{array}{l}\text { Berkurangnya rasa } \\
\text { pada kaki dan tangan }\end{array}$ \\
\hline 4 & Perubahan mental \\
\hline 5 & Kejang \\
\hline 6 & Mual dan muntah \\
\hline 7 & Sulit buang air kecil \\
\hline 8 & Urine berwarna coklat \\
\hline 9 & Tungkai bawah lemas \\
\hline 10 & Tubuh lemas \\
\hline 11 & Sakit pinggang \\
\hline 12 & Distensi perut \\
\hline 13 & Panas \\
\hline 14 & Menggigil \\
\hline 15 & $\begin{array}{l}\text { Adanya darah dalam } \\
\text { urine }\end{array}$ \\
\hline 16 & $\begin{array}{l}\text { Adanya nanah dalam } \\
\text { urine }\end{array}$ \\
\hline
\end{tabular}

\subsubsection{Mesin Inferensi}

Berikut gambar Diagram pohon klasifikasi untuk pelacakan kedepan penyakit ginjal

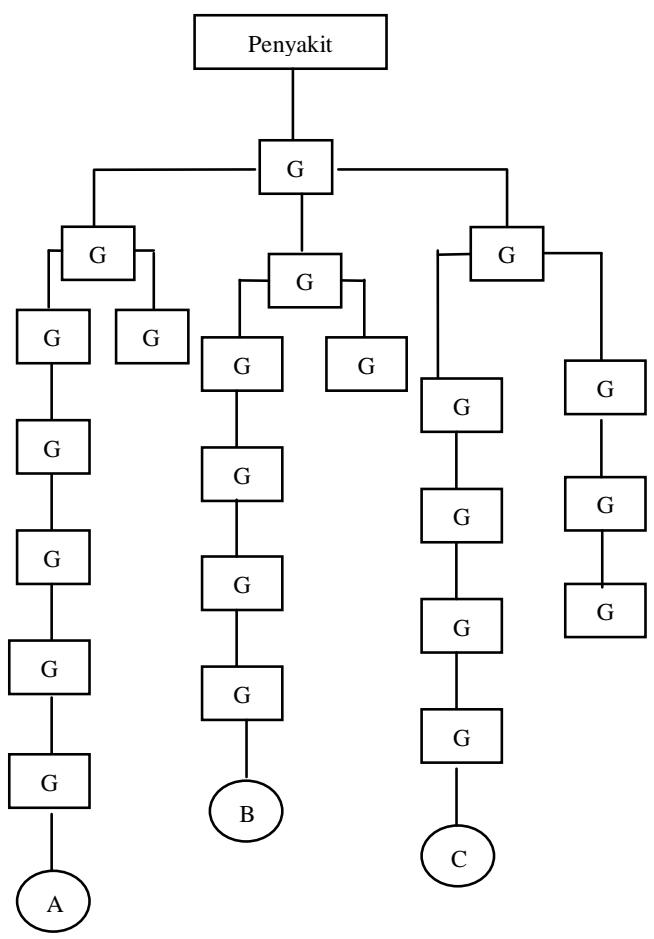

Gambar III.6 Mesin Inferensi dari Penyakit Ginjal

\section{HASIL DAN PEMBAHASAN}

\subsection{Implementasi}

Hasil implementasi dari sistem yang dibangun dari penulisan penelitian ini adalah sebuah sistem pakar untuk mendiagnosa kerusakan Ginjal, sistem pakar kerusakan Ginjal terdapat 5 form, yang terdiri dari form home, form info, form diagnosis dan form login.

Diawali dengan form home. Form home berisi tentang penjelasan serta sejarah sistem pakar kerusakan Ginjal. User dapat memperoleh informasi tentang keistimewaan teknologi komputer yang dapat menjangkau berbagai bidang ilmu seperti bidang kesehatan yang gunanya nanti untuk membantu memecahkan permasalahan yang dihadapi manusia dan mempermudah pekerjaan. Berikut desain tampilan interface dan penjelasan yang penulis rancang.

Pada form yang berikutnya terdapat form diagnosis. Pada form diagnosis berisi menu tampilan yaitu menu mulai yang ditunjukkan gambar IV.2 sebagai berikut :

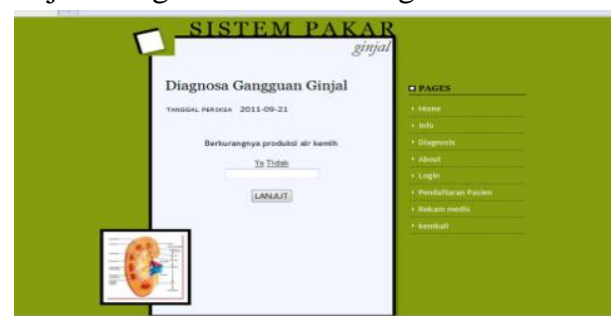

Gambar IV.1 Form Diagnosis

Didalam menu mulai apabila seorang user sudah memiliki nomor rekam medis dapat langsung melakukan diagnosa penyakit dari gejala -gejala yang akan akan di jawab user.

Selanjutnya user memasukkan nomor rekam medis kedalam form diagnosa seperti gambar IV.2 berikut:

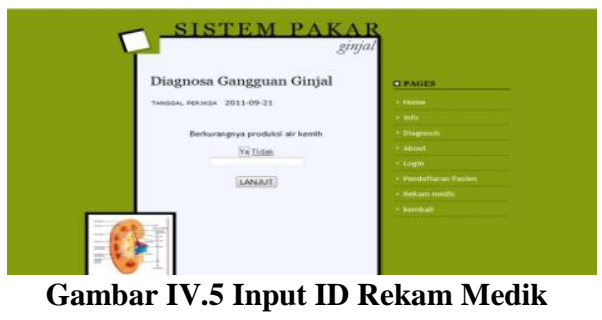

Setelah memasukkan nomor rekam medis seperti gambar diatas maka selanjutnya user dapat melakukan diagnosa penyakit dengan menekan link DIAGNOSA PENYAKIT seperti gambar IV.6 berikut : 


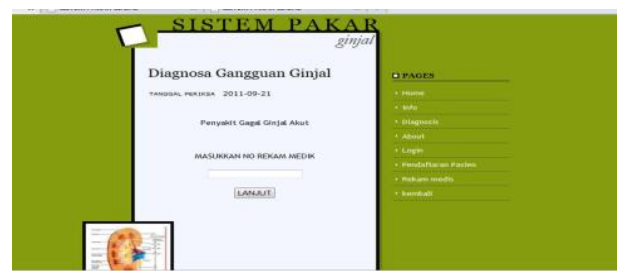

Gambar IV.6 Memulai Diagnosa

Pada form login berfungsi untuk menambah, merubah, menghapus database dengan cara mengetikkan Username dan Password seperti gambar IV.7 berikut :

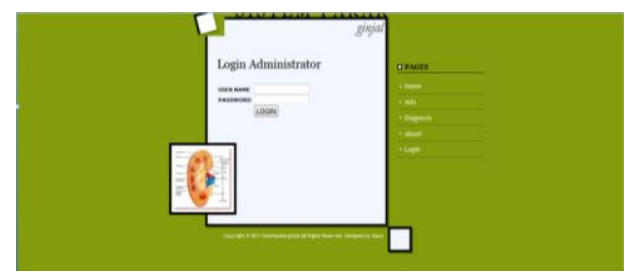

Gambar IV.7 Form Login

Setelah memasukkan Username dan Password kemudian klik tombol login maka hak akses akan dapat terbuka seperti beberapa gambar berikut ini :

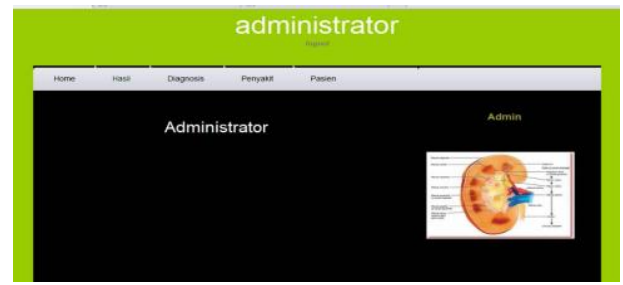

Gambar IV.8 Form Home Aministrator

Form selanjutnya adalah form hasil administrator. Pada form ini administrator dapat melihat dan menghapus data hasil diagnosis dari pasien seperti gambar IV.9 berikut :

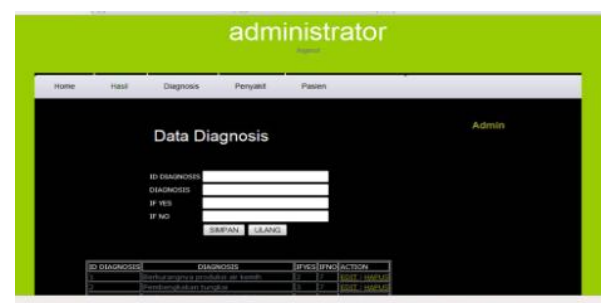

Gambar IV.9 Form Hasil

Selanjutnya adalah form diagnosis. Pada form ini administrator dapat mengelola data-data penyakit Ginjal beserta gejalagejalanya seperti pada gambar berikut :

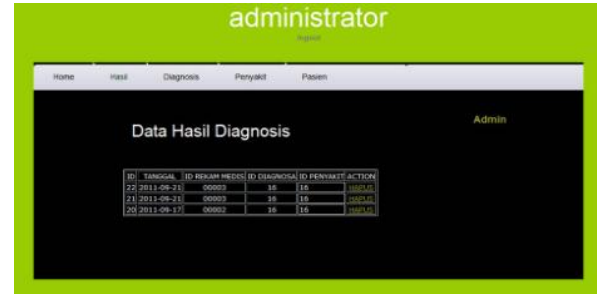

Gambar IV.10 Form Diagnosis

\section{KESIMPULAN DAN SARAN \\ 5.1 Kesimpulan}

Dari hasil penulisan penelitian yang telah penulis teliti, maka secara umum dapat diperoleh beberapa kesimpulan bahwa :

1. Pengobatan secara alamiah menggunakan herbal sangat dibutuhkan saat ini karena memiliki khasiat yang lebih baik dari obat-obatan yang mengandung zat kimia.

2. Sistem yang dirancang dapat meringankan tugas para dokter ahli, khususnya untuk mendiagnosa penyakit ginjal tanpa harus bertemu langsung dengan pasien. Pasien dapat mengakses dan menjawab pertanyaan-pertanyaan yang diajukan di dalam aplikasi tanpa batas waktu dan tempat.

3. Penggunaan sistem diagnosa penyakit ginjal dapat menambah pengetahuan manusia untuk mengetahui jenis penyakit ginjal

\subsection{Saran}

Dari hasil pengamatan penulis selama menyelesaikan penelitian ini. Beberapa saran yang mungkin dapat berguna bagi user antara lain :

1. Program ini dapat digunakan sebagai model untuk membuat sistem diagnosa penyakit lain.

2. Tampilan aplikasi masih dapat dikembangkan menjadi lebih menarik dengan menambahkan beberapa menu lagi di dalam aplikasi tersebut.

3. Solusi berupa pengobatan herbal masih dapat ditambah. Misalnya, cara meramu tanaman-tanaman yang berkhasiat sebagai obat tersebut.

4. Solusi berupa pencegahan terhadap penyakit yang diderita juga dapat dimasukkan demi menambah kesempurnaan sistem diagnosa.

5. Program masih dapat dikembangkan dengan meneliti kemungkinan penyakit lain yang mungkin diderita oleh user. 


\section{DAFTAR PUSTAKA}

[1] Anonim, Aplikasi program PHP dan MySQL untuk membuat website interaktif, edisi pertama, Yogyakarta: Andi 2004.

[2] Arhami, Muhammad, Konsep dasar sistem pakar, edisi pertama, Yogyakarta: Andi,2005.

[3] Kristiana, Fransisca, 24 Penyebab Ginjal rusak, Cetakan Pertama, Jakarta: Cerdas Sehat,2011.

[4] Jovan FN, Panduan Praktis membuat web dengan PHP untuk pemula, Cetakan pertama, Jakarta: Media Kita, 2007.

[5] Sunarfrihantono bimo. PHP dan MySQL untuk web, Edisi Kedua, Yogyakarta: Andi 2003.

[6] Silberschatz,dkk., database organization, Jakarta: Andi, 2002.

[7] Tatini B Indra, Flowchart, Algoritma dan Pemrograman Menggunakan Bahasa $\mathrm{C}++$ Builder, Edisi Pertama, Yogyakarta: Graha Ilmu, 2010.

[8] http:// jendrow. Wordpress .com /2009/08/28/download-appservdan-panduan-install-appserv/ 